\title{
The Determination of Inhibition Effect of Extracts of Thymbra sintenisii Bornm. et Aznav. Subsp on Angiotensin Converting Enzyme
}

\section{Tuğba GÜR ${ }^{1}$, Fatih KARAHAN ${ }^{2}$, Zehra BAŞ $^{3}$, Vedat TÜRKOĞLU}

\begin{abstract}
Angiotensin converting enzyme (ACE, peptidyldipeptidase A, EC 3.4.15.1) has got a significant role in the arrangement of blood pressure. ACE inhibitors usually play a part in the therapies of hypertension. Hypertension is an significant cardiovascular risk factor. The main purpose of the treatment is to reduce the incidence of hypertension. In this study, the inhibition effect of butanol and water extracts of Thymbra sintenisii Bornm. et Aznav. Subsp on angiotensin converting enzyme (ACE) activity in human plasma was investigated. ACE activity was calculated at $345 \mathrm{~nm}$ spectrophotometrically. Extracts of Thymbra sintenisii Bornm. et Aznav. subsp plant with water and butanol were made. The effectiveness of these extracts on ACE activity was researched. Water and butanol extracts of Thymbra sintenisii indicated inhibition impact on ACE. IC 50 values for water and butanol extracts of Thymbra sintenisii was measured to be $1.696 \mathrm{mg} \mathrm{mL}^{-1}$ and $0.395 \mathrm{mg} \mathrm{mL}^{-1}$ respectively. Inhibition type for water and butanol extracts of Thymbra sintenisii from Lineweaver-Burk chart was defined to be non-competitive inhibition. Synthetic ACE inhibitors are utilized in the therapy of hypertension. On the other hand, synthetic ACE inhibitors exhibit a large number of adverse effects. Therefore, ACE inhibitors have been newly researched from native herbs. These conclusions demonstrate that water and butanol extracts of Thymbra sintenisii plant may have an ACE inhibition capacity.
\end{abstract}

Keywords: Angiotensin converting enzyme, Inhibition, Thymbra sintenisii, Hypertension.

\footnotetext{
${ }^{1}$ Tuğba GÜR (Orcid ID: 0000-0001-7220-0210), Van Yüzüncü Y1l Üniversitesi Sağlık Hizmetleri Meslek Yüksek Okulu, Van, Türkiye.

${ }^{2}$ Fatih KARAHAN (Orcid ID: 0000-0002-4907-3935 ), Vedat TÜRKOĞLU (Orcid ID: 0000-0002-0935-1195), Van Yüzüncü Yıl Üniversitesi Fen Fak. Kimya Bölümü, Biyokimya ABD, Van, Türkiye,

${ }^{3}$ Zehra BAŞ (Orcid ID: 0000-0002-4071-9744), Van yüzüncü Yıl Üniversitesi Sağlık Bilimleri Fakültesi, Beslenme ve Diyetetik Bölümü, Van, Türkiye.

*Sorumlu Yazar/Corresponding Author: Tuğba GÜR, e-mail:tugbagur@yyu.edu.tr

Makale 10-13 Ekim 2018 tarihlerinde Van'da düzenlenen “Uluslararası Müzik, Dans ve Sağlık Kongresi'nde” Sözlü sunum (Abstract) olarak sunulmuştur.
}

Geliș tarihi / Received: 11-03-2020 Kabul tarihi / Accepted: 22-05-2020 


\section{INRODUCTION}

Hypertension is a major health problem that concerns more than 25 percent of the world (Kearney et al., 2005). It has got very common and serious condition that can lead to many health problem can be complicated. Hypertension is a serious cause of heart failure, peripheral vascular disease, renal failure, cerebrovascular, angina and cardiovascular diseases. The rate of these diseases increases compared to blood pressure.

Renin-angiotensin system is included in the arrangement of blood pressure and electrolyte metabolism. Renin is synthesized from jukstaglomerular cells of the kidney with a decrease in the blood pressure and volume of the kidney (Onat et al., 2006). Renin acts on the angiotensinogen in the liver and helps in the formation of Angiotensin I. The angiotensin converting enzyme (ACE, EC 3.4.15.1) transforms Angiotensin I into Angiotensin II, which is a direct vasoconstrictor, inactivates bradykinin, which is also a vasodilator. This powerful vasoconstrictor, angiotensin II, increases blood pressure by playing a role in the release of aldosterone by the adrenal cortex, the central nervous system, the sympathetic nervous system and the Na-steroid steroid (Li et al., 2003). High ACE activity causes to increased concentration of angiotensin II and hypertension. ACE is seen as part of the homeostatic mechanism responsible for maintaining blood pressure and electrolyte balance. Two specific ACE inhibitors, lisinopril and captopril, inhibit ACE and inhibit the transformation of angiotensin I to angiotensin II and have important roles in treating hypertension and protecting the electrolyte balance (Carretero and Oparil, 2000).

There are also other ACE inhibitors used in addition to drugs such as lisinopril and captopril. However, the drugs used as these inhibitors have many side effects. Therefore, the economic, safe and without adverse effects of ACE inhibitors from medicinal plants can provide an remarkable opportunity to find new potential pathways in the development of antihypertensive drugs. The plants are usually used as they are safe and preventable with a little adverse effects. For this reason, more efficient, scientifically complementary treatment pathways with the minumum repercussions are being researched (Leong et al., 2013). For example, the inhibition effects on ACE activity of $n$-hexane, methanol, and chloroform of Asperul glomerata, Prangos asperula, Calamintha origanifolia, Satureja thymbra, Sideritis perfoliata, Hyssopus officinalis, Marrubium radiatum, Erythraea centaurium, and Salvia acetabulosa were studied. Some of these plants, Marrubium radiatum and Salvia acetabulosa methanol extracts showed a powerfull inhibitory effect to ACE with $\mathrm{IC}_{50}$ of 72.7 and $52.7 \mu \mathrm{g} \mathrm{mL}^{-1}$, respectively (Loizzo et al.,2008). In one work, the impact of fatty acids isolated from Nigella sativa on pure ACE in human plasma was examined and the five isolated fractions indicated inhibition effect on ACE. The $\mathrm{IC}_{50}$ constants of the fractions were determined to be $1.597 \mathrm{mg} \mathrm{mL}^{-1}$ (Fr 1), $0.053 \mathrm{mg} \mathrm{mL}^{-1}$ (Fr 2), $0.527 \mathrm{mg}$ $\mathrm{mL}^{-1}$ (Fr 4), $0.044 \mathrm{mg} \mathrm{mL}^{-1}$ (Fr 5), and $0.136 \mathrm{mg} \mathrm{mL}^{-1}$ (Fr 6) (Basi and Turkoglu, 2018).

One of the plants used for medical purposes is Thymbra Sintenisii Bornm. et Aznav. The family Labiatae has got an significant role as a origin of medical and fragrant herbs of merchant significance. Thymbra L. is located within these aromatic genus. Thymbra (Labiatae) is demonstrated by the following 2 species and 4 taxa in the Flora of Turkey: T. spicata L. (var. spicata, var. intricata P.H.Davis) and T. sintenisii Bornm. \& Aznav. (subsp. sintenisii, subsp. isaurica P.H.Davis). Type of TS is a Mediterranean plant known for many years, with its hirsute purple flowering, shrub appearance. Tea or oil is used for analgesic effect in stomach pains. Regarding antiparasitic, antiseptic and blood circulation effects the Thymbra Sintenisii plant is used. In South Eastern Anatolia the plant's dried leaves and inflorescences are named as Zahter or Sater and are consumed as an antiseptic and inducing plant tea. It contains a variety of aromatic compounds mainly are carvacrol and thymol. In many of studies carvacrol, 
antioxidant, antibacterial, insecticides, anthelmintic, cholesterol-lowering, analgesic, antifungal, liver protective, and anti-carcinogenic properties such as has been shown (Fakıllı and Özgüven, 2012; Prasanth et al., 2014; Akkol et al., 2009; Koparal and Zeytinoğlu, 2003) .

Our aim in the work is to research and evaluate antihypertensive properties Thymbra Sintenisii Bornm. et Aznav via ACE inhibition. In the study, it was performed inhibition of ACE enzyme activity from human plasma. For this, it was prepared water and butanol extractions of Thymbra Sintenisii Bornm. The impact of these extracts on ACE inhibition was researched. To date, there is no study on the ACE inhibitory effect of water and butanol extracts of Thymbra Sintenisii Bornm. et Aznav. Therefore, we believe that this study contributes to the literature about this plant.

\section{MATERIALS AND METHODS}

\section{Chemical Materials}

HepesNa, N-[3-(2-Furyl) acryloyl]-L-phenylalanyl-glycyl-glycine (FAPGG), were purchased from Sigma-Aldrich. Butanol, methanol, chloroform, and hexane were obtained from VWR Chemicals. Entire other chemicals used were obtained from either Merck or Sigma-Aldrich.

\section{Plant Materials}

Thymbra sintenisii plant used in this study was purchased a local herbal store located in Mardin, Turkey. (August, 2018). The plant was identified and deposited at the Yüzüncü Yıl University, Faculty of Science, Department of Chemistry, Van, Turkey.

\section{Preparation of the human plasma}

Blood samples used to prepare human specimens were supplied from the Van Red Crescent Blood Center of Turkey. The blood specimens were put into tubes including EDTA, then the tubes were centrifuged 15 minute and $1500 \mathrm{rpm}$. The plasma was meticulously taken from the blood. And then plasma was again centrifuged for 1 hour $\left(4^{0} \mathrm{C}, 8500 \mathrm{rpm}\right)$ to uproot the ghosts and intact cells. The resulting plasma was then stored for using in the experiment.

\section{Activity Determination}

ACE activity was gauged spectrophotometrically at $345 \mathrm{~nm}$ by the decrease in the absorbance at $35^{\circ} \mathrm{C}$ accordingly the procedure of Holmquist, Bünning and Riordan (1979). $50 \mathrm{mM}$ HepesNa buffer, $0.3 \mathrm{M} \mathrm{NaCl}, 10 \mu \mathrm{M} \mathrm{ZnCl}_{2}$ and $1 \mathrm{mM}$ FAPGG added to the assay cuvette. One unit of activity was defined as the quantity of ACE that produces a $\triangle \mathrm{A} 345 / \mathrm{min}$. of 1.0 (Andújar-Sánchez et al., 2003; Holmquist et al.,1979).

\section{Preparation of Plant Extracts}

Thymbra sintenisii Bornm. et Aznav. Subsp was dried in the shade. Thymbra sintenisii was levigated with a blender. $37 \mathrm{~g}$ of the powder of Thymbra sintenisii was weighed and extracted by chloroform and methanol $\left(\mathrm{CHCl}_{3}\right.$ : $\left.\mathrm{MeOH} 1: 1\right)$ for 3 days and the $\mathrm{CHCl}_{3}$ : $\mathrm{MeOH}$ was evaporated. Subsequently, A two-phase mixture was atttained by adding $200 \mathrm{~mL}$ of bidistilled water: hexane (1:1) to the attained dry specimen. This biphasic mixture was poured to the division funnel and shaked and allowed to stand for division of the phases and these phases were meticulously separated from the tap of the division funnel. This procedure has been recurrent for three times.

Thereafter the hexane phase was evaporated, the resulting water phase was fractionated by adding $100 \mathrm{~mL}$ of ethyl acetate and the phases were splitted with a division funnel. This method has been recurrent for three times. The ethyl acetate phases were then assembled and evaporated in the evaporator and a dry sample was attained. After that, the ethyl acetate phase was removed, the resulting water phase 
was fractionated by adding $100 \mathrm{~mL}$ of butanol and the phases were separated with a separatory funnel. This method has been recurrent for three times. The butanol phases were then assembled and evaporated in the evaporator and a dry specimen was attained $38 \mathrm{mg}$ was received from the resulting dry sample and dissolved in $3 \mathrm{~mL}$ of bidistilled water. This manner the butanol extract was attained.

For all that the solvent was removed in the last water phase and a dry sample was attained. $45 \mathrm{mg}$ was received from the resulting dry specimen and dissolved in $1 \mathrm{~mL}$ of bidistilled water. The water extract was provided in this way. The extracts were kept at $4{ }^{0} \mathrm{C}$ then the extracts were used in the evaluation.

\section{ACE Inhibition Assay}

In this study, human plasma was preferred to evaluate ACE activity. Two tubes were received as blind and specimen and $100 \mu \mathrm{L}$ of plasma containing ACE was incorporated to each tube. Then, $900 \mu \mathrm{L}$ of HEPES buffer (50 mM HEPES, $0.3 \mathrm{M} \mathrm{NaCl}, 10 \mu \mathrm{M} \mathrm{ZnCl}_{2} \mathrm{pH} 7.5$ ) was incorporated to the blind tube without substrate (FAPGG) and stirred. The spectrophotometer was reset with a blind cuvette. To the

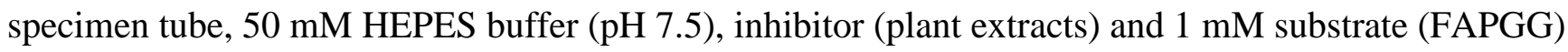
were added to be total volume to $1000 \mu \mathrm{L}$ and stirred and absorbance at $345 \mathrm{~nm}$ was measured. The specimen tube was incubated for 30 minutes at $35^{\circ} \mathrm{C}$. Then 30 minutes, the absorbance of the tubes at $345 \mathrm{~nm}$ was determined and the quantity of reduce in absorbance was measured.

$$
\mathrm{A}(\mathrm{ACE} \text { Activity })=(\Delta \mathrm{OD} / 0.517) \times(\mathrm{Vc} / \mathrm{Ve}) \times \mathrm{f},
$$

where $\triangle \mathrm{OD}$ is the reduce in the absorbance at $345 \mathrm{~nm}$ per minute, $\mathrm{Vc}$ is total reaction volume, $\mathrm{Ve}$ is the volume of enzyme solution (plasma hemolysate), $\mathrm{f}$ is the dilution coefficient, and 0.517 is the millimolar absorption coefficient of FAPGG.

The ACE inhibitory activity (inhibition \%) was found from the calibration curve and computed by the following equation:

$\%$ ACE inhibition = Uninhibited activity - Inhibited activity / Uninhibited activity $\mathrm{x} 100$

\section{RESULTS AND DISCUSSION}

The Thymbra sintenisii plant material was successively extracted by maceration using methanol and chloroform $\left(\mathrm{CHCl}_{3}: \mathrm{MeOH}\right.$ 1:1). The crude extract was obtained from solvent evaporation under vaccum. And then water and butanol extracts were composed by using this crude material. We investigated the inhibitory activities of water and butanol extracts of Thymbra sintenisii Bornm. et Aznav on ACE in human plasma.

Herein, the impact of water and butanol extracts of Thymbra sintenisii on ACE activity were researched. Water and butanol extracts of Thymbra sintenisii plant demonstrated inhibition effect on Angiotensin Converting Enzyme. $\mathrm{IC}_{50}$ valuations for water and butanol extracts of Thymbra sintenisii were designated as $1.696 \mathrm{mg} \mathrm{mL}^{-1}$ and $0.395 \mathrm{mg} \mathrm{mL}^{-1}$, respectively (Figure 1,2). The inhibition type for inhibitors was found as non-competitive with Lineweaver-Burk chart (Figure 3, 4). 


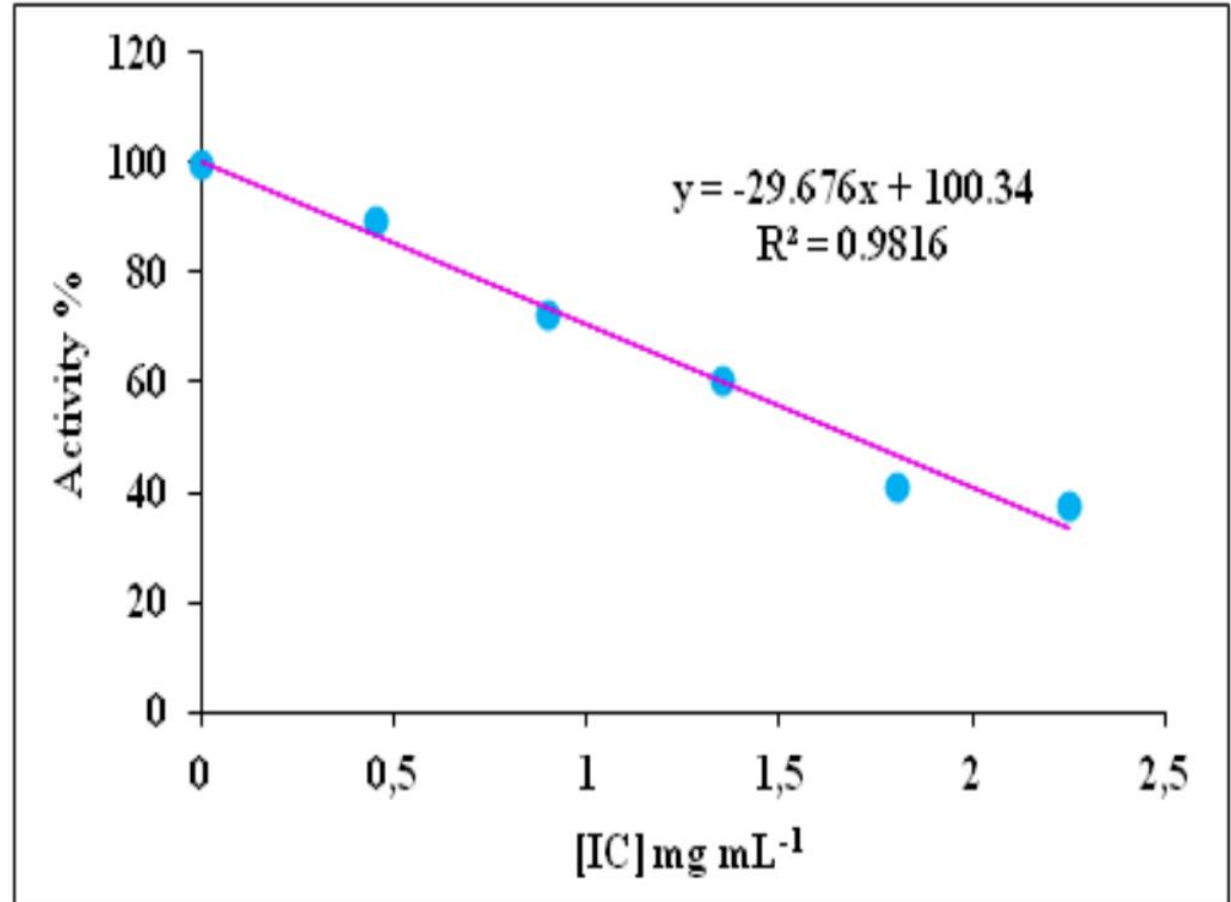

Figure 1. The inhibition impact of Thymbra sintenisii water extracts on the ACE. Five dissimilar Thymbra sintenisii water extracts (from 0.45 to $2.25 \mathrm{mg} \mathrm{mL}^{-1}$ ) on ACE activity were designated.

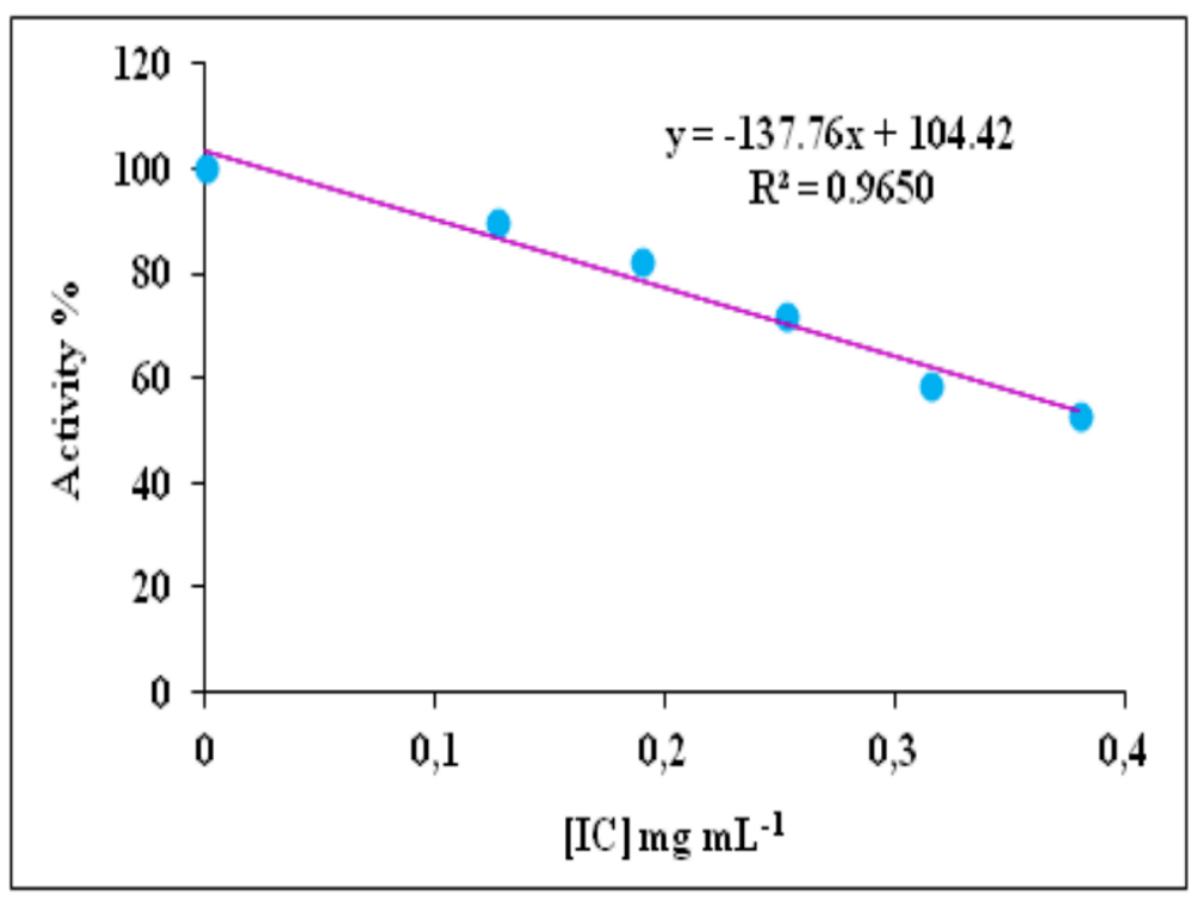

Figure 2. The inhibition impact of Thymbra sintenisii butanol extracts on the ACE. Five dissimilar Thymbra sintenisii butanol extracts (from 0.13 to $0.38 \mathrm{mg} \mathrm{mL}^{-1}$ ) on ACE activity were designated. 


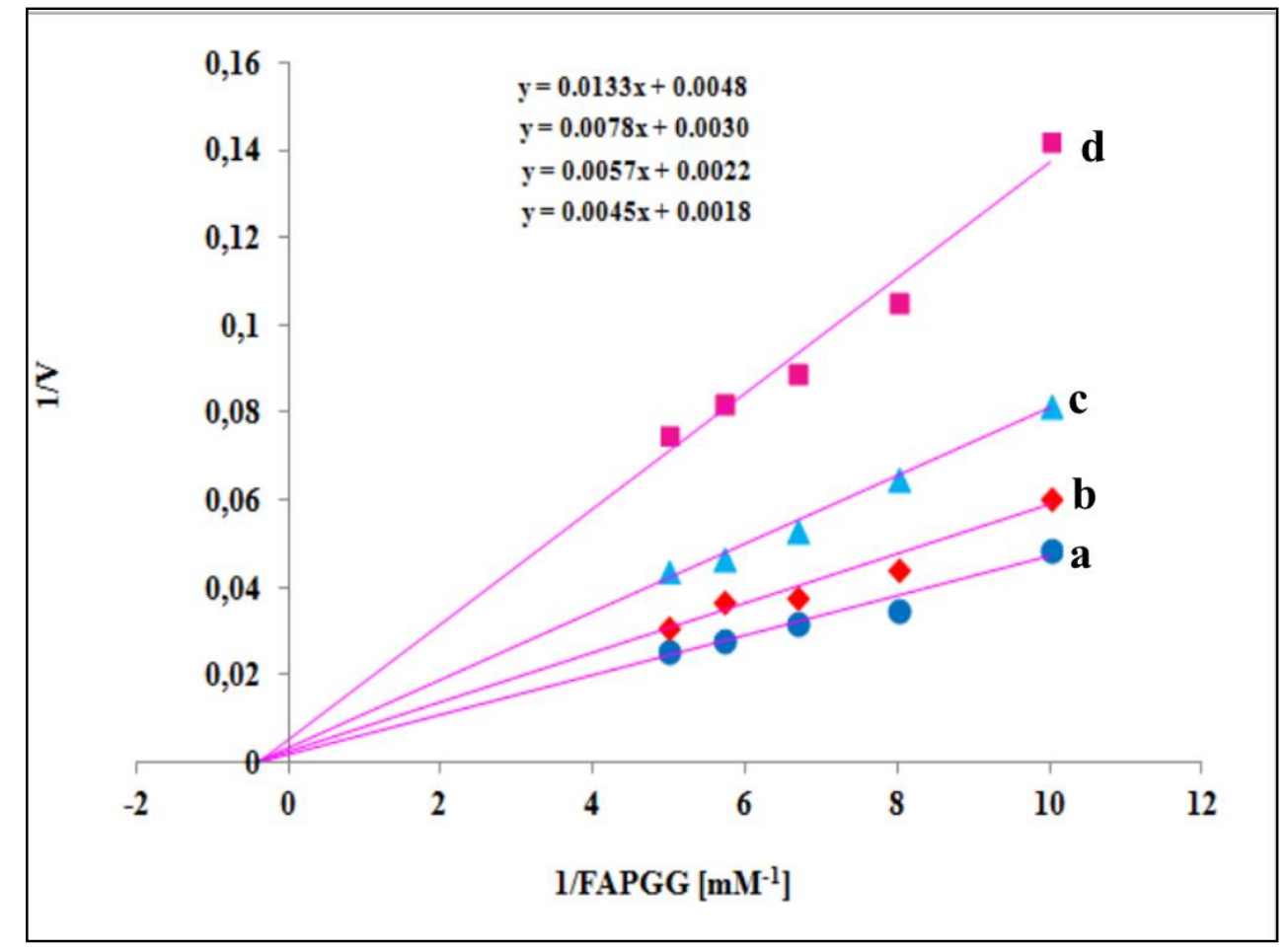

Figure 3. Lineweaver-Burk chart by five distinct substrate concentrations (FAPGG) and three different Thymbra sintenisii water extract concentrations (control (a), $0.45 \mathrm{mg} \mathrm{mL}^{-1}$ (b), $1.35 \mathrm{mg} \mathrm{mL}^{-1}$ (c), $2.25 \mathrm{mg} \mathrm{mL}^{-1}$ (d) used for the definition of inhibition sort.

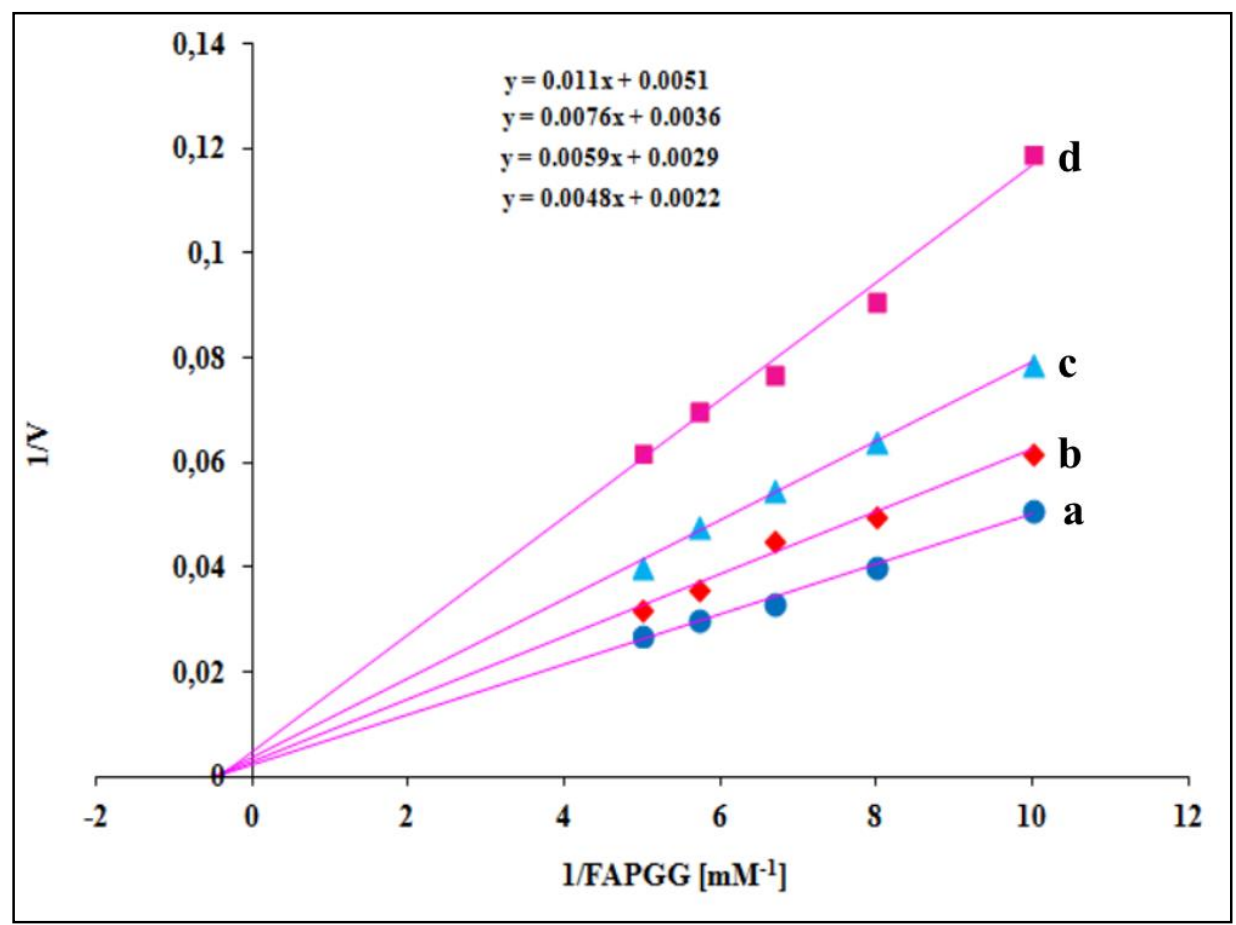

Figure 4. Lineweaver-Burk chart by five dissimilar substrate concentrations (FAPGG) and three dissimilar Thymbra sintenisii butanol extract concentrations (control (a), $0.13 \mathrm{mg} \mathrm{mL}^{-1}$ (b), $0.25 \mathrm{mg}$ $\mathrm{mL}^{-1}$ (c), and $0.38 \mathrm{mg} \mathrm{mL}^{-1}$ (d) used for the definition of inhibition sort. 
Plants and bioactive materials that obtained of herbs were employed as conventional medication to treat diseases throughout history. In these days, treatment with plants still continues significantly in various cultures. According to World Health Organization datas, almost $80 \%$ of people around the world uses plants for primary health care. The herbal substances even have got a significant place in health care for remaining $20 \%$ (Ranilla et al., 2010). Hypertension is a widespread progressive disrupt causing to some chronic diseases like that cardiovascular disease, stroke, renal disease and diabetes. ACE inhibitory medicines are the first class therapeuticals since decades. However, exposure to drugs for a certain period of time may lead to repercussions such as lack of power, triedness, sleepiness, inability, cool hands and feet, crisis, sleeplessness, unusual heartthrobs, skin itching, dried mouth, dizziness, coughing, and angioneuretic edema (Israili and Hall, 1992). Some new options have been discovered obviously that can replace of these medicines. Many plants like Garlic (Allium sativum), Lime blossom (Tilia europea), Kudzu (Pueraria lobata), Mistletoe (Viscum album), Valerian (Valeriana officinalis), and Saffron (Crocus sativus) could be used as a natural source for developing newer therapeutic agents. Nowadays, native substances and their reproductions contain more than $50 \%$ of all drugs in clinical application (Raji et al., 2012).

In this study, the impact of Thymbra sintenisii plant extracts on ACE was researched. Water and butanol extracts of Thymbra sintenisii plant demonstrated inhibitor impact on ACE. Thymbra sitenisii Bornm et. Aznav is used a medically plant in Anatolia, Turkey. Meanwhile, this herb has germicidal, and stimulative impacts. In many studies conducted with plants, the inhibitory impact was shown on ACE enzyme. According to a study was realized the inhibition impact of hydroalcoholic extracts of $N$. jatamansi, $P$. ferulacea and $M$. vulgare on ACE activity. $\mathrm{IC}_{50}$ values of these plants were found as 2.147 $\mathrm{mg} \mathrm{mL} \mathrm{m}^{-1}, 4.057 \mathrm{mg} \mathrm{mL}^{-1}$ and $0.791 \mathrm{mg} \mathrm{mL}^{-1}$, respectively. The minimum value of $\mathrm{IC}_{50}$ was $M$. Vulgare (Namjoyan et al., 2015). In our study $\mathrm{IC}_{50}$ values for water and butanol extracts of Thymbra sintenisii plant were found as $1.696 \mathrm{mg} \mathrm{mL}^{-1}$ and $0.395 \mathrm{mg} \mathrm{mL}^{-1}$, respectively According to our study, inhibitory impact of water and butanol extracts of Thymbra sintenisii is more than their plants extracts. So, the inhibitor values of our study are the best compared to other studies.

The drugs was used in hypertensive teratment has side effects so, investigations was turned into biological sources such as herb extracts. It has been demonstrated that the methanolic extracts of Musa X paradisiaca inhibited ACE activity by $68.63 \%-98.3 \%$ (Acharya et al., 2016). In other work, the ACEinhibitory effect of citrus leaf extracts were showed in rats fed with palm oil heated five times (Siti et al., 2017) . Besides herb extracts, food sourced ACE-inhibitory peptides as using an option to synthetical medicines and are regarded ideally accepted class of bioactive peptides (Jimsheena and Gowda,2011). In South Africa, twenty traditional plants were investigated against to ACE for their antihypertensive properties. Among these plants, Adenopodia spicata leaves were showed the most inhibitory effect (97\%) (Duncan et al., 1999). In another work, butanol and water extracts of Juniperus excelsa Bieb. fruits inhibited ACE activity purified from human plasma. $\mathrm{IC}_{50}$ values for water and butanol extracts of Juniperus excelsa fruits were designated as $5.790 \mathrm{mg} \mathrm{mL}^{-1}$ and $2.858 \mathrm{mg} \mathrm{mL}^{-1}$ respectively (Basi et al., 2019). In a study examining the efficacy of both GSSG and GSH on human plasma ACE activity, GSSG peptide demonstrated activator impact. GSH demonstrated inhibitior impact on ACE efficiency and lisinopril was utilized as spesific inhibitor. $\mathrm{IC}_{50}$ values for lisinopril and GSH were calculated as 0.781 $\mathrm{nM}$ and $16.2 \mu \mathrm{M}$, respectively (Basi and Turkoglu, 2019).

At the same time, many recent studies have investigated the inhibition effect on ACE activity of peptides from natural sources. For example, in one study, Three ACE inhibitor peptides were isolated from broccoli protein hydrolysates and identified as IPPAYTK, LVLPGELAK and 
TFQGPPHGIQVER. The IC 50 values of these peptides were 23.5, 184.0, and 3.4 $\mu \mathrm{M}$, respectively (Dang et al., 2019). The Gly-Val-Gly-Ser-Pro-Tyr hexapeptide obtained from the pearl oyster (Pinctada fucata) shell protein hydrolyzate showed an inhibition effect on $\mathrm{ACE}$ and the $\mathrm{IC}_{50}$ value was found to be 5.82 $\mu \mathrm{g} \mathrm{mL} \mathrm{mL}^{-1}$ (Sasaki et al., 2019). SAGGYIW and APATPSFW peptides isolated from wheat gluten had a significant inhibition effect on ACE activity with $\mathrm{IC}_{50}$ values of $0.002 \mathrm{mg} \mathrm{mL}^{-1}$ and $0.036 \mathrm{mg} \mathrm{mL}^{-1}$, respectively (Zhang et al., 2020). In other words, natural sources and natural compounds obtained from these sources constitute an important research area as ACE inhibitors.

Enzyme efficiency is determined in the tampon system. The polarity has a big significance in terms of creation a homogeneous solution in the tampon medium. In our work, water and butanol phase extracts inhibited the enzyme efficiency. At the same time, because of the nanostructures of butanol, the polar molecules have a great affinity for this solvent. Therefore, butanol extract had a significant effect on ACE activity.

\section{CONCLUSION}

Traditional herbal teas are usually used by the people in the water by boiling or brewing method is prepared. The polar phase was more effective in our study. This situation is explained above. This study may be a preliminary study with this plant. In later times, the active substance isolation of Thymbra sintenisii Bornm. et Aznav plant can be made and their effects on this enzyme can be investigated.

\section{REFERENCES}

Acharya J, Karak S, De B,2016. Metabolite Profile and Bioactivity of Musa X Paradisiaca L. Flower Extracts. J. Food Biochem, 40:724-730.

Akkol EK, Avci G, Kucukkurt I, Keles H, Tamer U, Ince S, Yesilada E, 2009. Cholesterol-reducer, antioxidant and liver protective effects of Thymbra spicata L. var. Spicata. J Ethnopharmacol, 126:314-319.

Andújar-Sánchez M, Cámara-Artigas A, Jara-Pérez V, 2003. Purification of angiotensin 1 converting enzyme from pig lung using concanavalin-A sepharose chromatography. Journal of Chromatography B, 783:247-252.

Basi Z, Turkoglu N, Turkoglu V, Karahan F, 2019. In vitro effect of ethyl acetate, butanol and water extracts of Juniperus excelsa Bieb. on Angiotensin Converting Enzyme purified from human plasma. Chemical Papers, 73:2525-2533.

Basi Z, Turkoglu V, 2018. Purification of angiotensin-converting enzyme from human plasma and investigation of the effect of some active ingredients isolated from Nigella sativa L. Extract on the enzyme activity. Biomedical Chromatography, 32: 4175.

Basi Z, Turkoglu V, 2019. In vitro effect of oxidized and reduced glutathione peptides on angiotensin converting enzyme purified from human plasma. Journal of Chromatography B, 1104:190-195.

Carretero OA, Oparil S, 2000. Essential hypertension. Part I: definition and etiology. Circulation, 101:329-335.

Dang Y, Zhou T, Hao L, Cao J, Sun Y, Pan D, 2019. In vitro and in vivo Studies on the angiotensinconverting enzyme inhibitory activity peptides isolated from broccoli protein hydrolysate. Journal of Agricultural and Food Chemistry, 67(24): 6757-6764.

Duncan AC, Jager AK, Van Staden J, 1999. Screening of Zulu medicinal plants for angiotensin converting enzyme (ACE) inhibitors, J Ethnopharmacol, 68:63-70.

Fakıllı O,Özgüven M,2012. Inventory of researches on thyme (Thymus vulgaris L) in Turkey. ÇÜ Fen Mühendislik Bil Derg, 27:54-66. 
Holmquist B, Bünning P, J.F. Riordan JF, 1979. A continuous spectrophotometric assay for angiotensin converting enzyme. Analytical Biochemistry, 95:540-548.

Israili ZH, Hall WD,1992. Cough and angioneurotic edema associated with angiotensin-converting enzyme inhibitor therapy, A review of the literature and pathophysiology. Ann Inter Med, 117:234-42.

Jimsheena VK, Gowda LR, 2011. Angiotensin I-Converting Enzyme (ACE) Inhibitory Peptides Derived from Arachin by Simulated Gastric Digestion. Food Chem, 125:561-569.

Kearney PM, Whelton M, Reynolds K, Muntner P, Whelton PK , He J, 2005. Global burden of hypertension: analysis of worldwide data. Lancet, 365: 217-223.

Koparal AT, Zeytinoğlu M ,2003. Effects of carvacrol on a human non-small cell lung cancer (NSCLC) cell line A549. Cytotechnolog, 43:149-154.

Leong XF, Mustafa MR, Jaarin K, 2013. Nigella sativa and its protective role in oxidative stress and hypertension. Evidence based Complementary and Alternative Medicine, 2013:120732.

Li GH, Le GW, Shi YH, Shrestha S, 2003. Angiotensin I - converting enzyme inhibitory peptides derived from food proteins and their physiological and pharmacological effects. Nutr. Res, 24 : 469-486.

Loizzo MR, Saab AM, Tundis R, Menichini F, Bonesi M, Piccolo V, Statti GA, de Cindio B, Houghton PJ, Menichini F, 2008. In vitro inhibitory activities of plants used in Lebanon traditional medicine against angiotensin converting enzyme (ACE) and digestive enzymes related to diabetes. $\mathbf{J}$ Ethnopharmacol., 119:109-16.

Namjoyan F, Azemi ME, Abdollahi E, Goudarzi N, Nikan K, 2015. Angiotensin I Converting Enzyme Inhibitory Activities of Hydroalcoholic Extracts of Nardostachys jatamansi, Prangos ferulacea and Marrubium vulgare. Jundishapur J Nat Pharm Prod, 10:17255.

Onat T, Emerk K, Sözmen E, 2006. İnsan Biyokimyası. Palme Yayınc1lı, s.813, Ankara.

Prasanth RV, Ravi Vital K, Varsha P, Satyan S , 2014. Review on Thymus vulgaris traditional uses and pharmacological properties. Med Aromat Plants, 3:164-167.

Raji IA, Mugabo P, Obikeze K, 2012. Effect of Tulbaghia violacea on the blood pressure and heart rate in male spontaneously hypertensive Wistar rats. J Ethnopharmacol, 140:98-106.

Ranilla LG, Kwon VI, Apostolidis E, Shetty K , 2010. Phenolic compounds, antioxidant activity and in vitro inhibitory potential against key enzymes relevant for hyperglycemia and hypertension of commonly used medicinal plants, herbs and spices in Latin America. Bioresour Technol, 101:4676-89.

Sasaki C, Tamura S, Tohse R, Fujita S, Kikuchi M, Asada C, Nakamura Y, 2019. Isolation and identification of an angiotensin I-converting enzyme inhibitory peptide from pearl oyster (Pinctada fucata) shell protein hydrolysate. Process Biochemistry, 77: 137-142.

Siti HN, Kamisah Y, Nur Iliyani MI, Mohamed S, Jaarin K, 2017. Citrus Leaf Extract Reduces Blood Pressure and Vascular Damage in Repeatedly Heated Palm Oil Diet-Induced Hypertensive Rats. Biomed. Pharmacother, 87:451-460.

Zhang P, Chang C, Liu H, Li B, Yan Q, Jiang Z, 2020. Identification of novel angiotensin I-converting enzyme (ACE) inhibitory peptides from wheat gluten hydrolysate by the protease of Pseudomonas aeruginosa. Journal of Functional Foods. 65: 103751. 